\title{
Transposed-Letter Priming Effects for Close Versus Distant Transpositions
}

\author{
Manuel Perea, ${ }^{1}$ Jon Andoni Duñabeitia, ${ }^{2}$ and Manuel Carreiras ${ }^{2}$ \\ ${ }^{1}$ Universitat de València, Valencia, Spain \\ ${ }^{2}$ Universidad de La Laguna, Tenerife, Spain
}

\begin{abstract}
Transposing two internal letters of a word produces a perceptually similar item (e.g., CHOLOCATE being processed as CHOCOLATE). To determine the precise nature of the encoding of letter position within a word, we examined the effect of the number of intervening letters in transposed-letter effects with a masked priming procedure. In Experiment 1, letter transposition could involve adjacent letters (chocloate-CHOCOLATE) and nonadjacent letters with two intervening letters (choaolcte-CHOCOLATE). Results showed that the magnitude of the transposed-letter priming effect - relative to the appropriate control condition - was greater when the transposition involved adjacent letters than when it involved nonadjacent letters. In Experiment 2, we included a letter transpositions condition using nonadjacent letters with one intervening letter (cholocate-CHOCOLATE). Results showed that the transposed-letter priming effect was of the same size for nonadjacent transpositions that involved one or two intervening letters. In addition, transposed-letter priming effects were smaller in the two nonadjacent conditions than in the adjacent condition. We examine the implications of these findings for models of visual-word recognition.
\end{abstract}

Keywords: perceptual similarity, masked priming, word recognition

How does the brain encode the letter positions within a word? This is a key question for the choice of an input coding scheme in computational models of visual-word recognition (e.g., how can the cognitive system distinguish between causal and casual?). In recent decades, a growing body of data has shown that transposing two adjacent letters of a word (e.g., jugde from judge) results in a perceptually similar word that can be read with little cost (Grainger \& Whitney, 2004; Rayner, White, Johnson, \& Liversedge, 2006). In masked priming experiments, transposed-letter nonword primes not only produce form-priming effects relative to the appropriate orthographic control (e.g., jugde$J U D G E$ vs. jupte-JUDGE; Perea \& Lupker, 2003b; see also Christianson, Johnson, \& Rayner, 2005; Duñabeitia, Perea, \& Carreiras, 2007; Forster, Davis, Schoknecht, \& Carter, 1987; Perea \& Carreiras, 2006a, 2006b; Schoonbaert \& Grainger, 2004), but also associative-priming effects (e.g., jugde-COURT vs. ocaen-COURT; Perea \& Lupker, 2003a). Furthermore, transposed-letter effects have also been found in normal sentence reading when the participants' eye movements are monitored (Johnson, 2007; Johnson, Perea, \& Rayner, 2007; Rayner et al., 2006).

The presence of transposed-letter effects has posed a serious challenge for the coding scheme of computational models of word recognition that assume that the positions of the letters are established very early in processing ("position-specific" coding schemes; e.g., the interactive-activation model, Rumelhart \& McClelland, 1982; dual-route cascaded model, Coltheart, Rastle, Perry, Ziegler, \& Langdon, 2001; multiple read-out model, Grainger \& Jacobs, 1996). In these models, a nonword created by transposing two letters (e.g., jugde) would be no more similar to its base word (judge) than a nonword created by simply replacing those letters (jubpe).

Nonetheless, the presence of transposed-letter similarity effects is a natural consequence of the input coding scheme in the Self-Organising Lexical Acquisition and Recognition (SOLAR) model (Davis, 1999) and in open-bigram models (Sequential Encoding Regualted by Inputs to Oscillators (SERIOL) model, Whitney, 2001; discrete open-bigram model, Grainger \& van Heuven, 2003). The SOLAR model uses a spatial coding scheme in which letter codes are position independent. That is, transposed-letter nonwords CAIS$N O$ and CANISO share the same set of letter nodes with the base word: $C A S I N O$. These three items would be coded differently because they would produce different activation patterns across the letter nodes they share (e.g., in the word $C A S I N O$, the letter node corresponding to $C$ is the one associated with the highest activation value, the letter node corresponding to the letter $A$ is associated with a slightly smaller activation value, etc.). The continuous open-bigram model (SERIOL model, Whitney, 2001, in press; Whitney \& Cornelissen, in press) uses a "letter-tagging" coding scheme, in which each letter is marked for the ordinal position in which it occurs within a letter string (e.g., CASINO: $C-1, A-2, S-3, I-4, N-5, O-6$ ), with the relevant letter nodes receiving differential levels of activation as a function of position. This letter-tagging scheme is accompanied by the activation of open bigrams - ordered pairs of letters - so that $C A S I N O$ would be represented by the following bigram nodes: $C A, A S, S I, I N, N O, C S, C I, A I, A N, S N, S O$, and $I O$ - a maximum allowable separation of two letters is assumed for the open bigrams in the current version of the model (i.e., $C N$ or $C O$ would not be activated; see Whitney, 
Table 1. Similarity match values for the SOLAR, open-bigram model, and SERIOL models for the different prime-target conditions

\begin{tabular}{lccc}
\hline & \multicolumn{3}{c}{ Type of prime } \\
\cline { 2 - 4 } & Transposed-letter & Double-substitution & Priming \\
\hline SOLAR model & & & 0.19 \\
Adjacent & 0.96 & 0.77 & 0.11 \\
Nonadjacent (1 between) & 0.88 & 0.77 & 0.04 \\
Nonadjacent (2 between) & 0.81 & 0.77 & 0.42 \\
Open-bigram model & & & 0.49 \\
Adjacent & 0.91 & 0.51 & 0.09 \\
Nonadjacent (1 between) & 0.76 & 0.53 & 0.28 \\
Nonadjacent (2 between) & 0.62 & & 0.10 \\
SERIOL model & & 0.61 & 0.06 \\
Adjacent & 0.89 & 0.59 & 0.57 \\
Nonadjacent (1 between) & 0.69 & & \\
Nonadjacent (2 between) & 0.63 & &
\end{tabular}

in press). These bigrams would be weighted so that adjacent bigrams (e.g., $C A$ ) would have a greater weight than close nonadjacent bigrams $(C S)$, and these, in turn, would have a greater weight than bigrams that are two letters away (CI). Grainger and van Heuven (2003) and Grainger and Whitney (2004) presented a binary version of the open-bigram model, in which the relative position of a letter is coded on the basis of its local context (i.e., coded with the context of letters that co-occur within the string, up to a limit of two intervening letters). This local context corresponds to a set of open-bigram units. Unlike the SERIOL model, all the activated bigrams in the open-bigram model have the same weight. ${ }^{1}$

In the SOLAR and open-bigram models, the degree of similarity between a word and its corresponding transposed-letter nonword is a function of the distance between their constituent letters. That is, transposed-letter priming effects should diminish in magnitude as a function of the number of intervening letters (i.e., caisno-CASINO would be more similar than caniso-CASINO). As Grainger (in press) recently indicated, "clearly what we need now are parametric manipulations of $(.$.$) the size of the transposi-$ tions (number of intervening letters)." The aim of this study is to fill this gap. There is empirical evidence that shows that transposed-letter priming effects also occur with nonadjacent letter positions with one intervening letter (caniso-CASINO vs. the orthographic control caviro-CASINO; e.g., Lupker, Perea, \& Davis, in press; Perea \& Lupker, 2004); however, these studies did not examine the size of the transposedletter priming effect for adjacent transpositions.

The main goal of the present experiments is to examine the effect of the number of intervening letters in transposedletter priming effects. Specifically, letter transpositions could involve adjacent letters (e.g., chocloate-CHOCOLATE; Experiments 1 and 2), nonadjacent letters with one intervening letter (cholocate-CHOCOLATE; Experiment 2), and nonadjacent letters with two intervening letters (choaolcteCHOCOLATE; Experiments 1 and 2). The SOLAR and open-bigram models provide estimates concerning the magnitude of the transposed-letter priming effects for adjacent and nonadjacent letter positions relative to the appropriate orthographic control condition. In terms of calculated similarity, and using the default parameters of the models in the MatchCalculator application, ${ }^{2}$ the average similarity match between the prime-target pairs in the different experimental conditions for the 240 experimental words is presented in Table 1. (Obviously, the similarity match between two identical pairs would be 1.) For the three models, the similarity match between the prime and the target would be stronger for the chocloate-CHOCOLATE pairs than for cholocateCHOCOLATE pairs, and for cholocate-CHOCOLATE pairs than for choaolcte-CHOCOLATE pairs (see Table 1).

Not surprisingly, all three models predict lower levels of priming as the number of intervening letters increases. More specifically, the SOLAR model predicts a clear transposedletter effect for adjacent letter positions (0.19), which is notably less for nonadjacent letter positions with a letter in between (0.11), and in turn, the effect is predicted to be quite small when the nonadjacent letters have two letters in between (0.04). The (binary) open-bigram model predicts a robust transposed-letter effect for the adjacent letter transposition (0.42), a medium-size effect for the nonadjacent letter transpositions (with one intervening letter; 0.25), and a small effect for the nonadjacent letter transpositions (with two intervening letters; 0.09). Finally, the SERIOL model also predicts a similar pattern, except that in the case of

\footnotetext{
1 In a recent paper, Grainger, Granier, Farioli, Van Assche, and van Heuven (2006) indicated that open bigrams would be weighted according to the amount of distance between the component letters in the input string. In this case, the predictions of this "overlap open-bigram" model would be close to those provided by the SERIOL model.

2 We obtained the match scores of the three input coding schemes by using the application MatchCalculator (version 1.9), written by Colin Davis. This application is available at: http://www.pc.rhul.ac.uk/staff/c.davis/Utilities/MatchCalculator.exe.
} 
the SERIOL model, there is a robust difference between the transposed-letter priming effect for the adjacent letter positions $(0.28)$ and the transposed-letter priming effect for the two nonadjacent letter positions $(0.10$ and 0.06 for the case of one and two intervening letters, respectively).

In total, in the present study, we wished to parametrically examine the effect of the number of intervening letters in transposed-letter priming effects. Transposed-letter priming effects were evaluated relative to the appropriate orthographic controls (i.e., double-substitution nonwords as primes). In Experiment 1, the nonadjacent transposed-letter condition has two intervening letters (choaolcte-CHOCOLATE vs. the control choeolste-CHOCOLATE), while in Experiment 2, the nonadjacent transposed-letter primes has either one or two intervening letters (both cholocate-CHOCOLATE and choaolcte-CHOCOLATE vs. chotonate-CHOCOLATE and choeolste-CHOCOLATE).

Prior research has shown that the transposition of two vowels decreases the magnitude of transposed-letter priming effects in the lexical decision task (e.g., anamil-ANIMAL; Perea \& Lupker, 2004; see also Lupker et al., in press). For that reason, all letter transpositions in the present experiments involved two consonants or a vowel and a consonant: Lupker, Perea, and Davis (2005) reported a robust effect for both consonant-vowel and consonant-consonant transpositions in a masked priming lexical decision task (see also Christianson et al., 2005, for a similar pattern in a masked priming naming task).

\section{Experiment 1}

In the present experiment, we examined whether transposedletter priming effects could be obtained when transposing two nonadjacent internal letters with two intervening letters. For comparison purposes, we included a transposed-letter priming condition in which two adjacent internal letters were transposed. As in previous work, we employed double-substitution primes as the orthographic control condition. What we should also indicate is that, in a recent study, Guerrera and Forster (2008) found a robust transposed-letter priming effect in long (eight-letter) words with rather extreme TL manipulations (e.g., using several adjacent transpositions, as in siedawkl-SIDEWALK). Guerrera and Forster used an unrelated control condition as the baseline; however, the use of an unrelated condition as a baseline makes it difficult to come to any strong conclusions about the specific role of letter positions versus letter identities in their experiments (see Perea \& Lupker, 2003a, 2003b, for discussion).

To increase statistical power - masked priming effects are typically small in magnitude - we used an elevated number of items per experimental condition (60 words per condition). As indicated above, the SOLAR and open-bigram models predict a much stronger transposed-letter priming effect when the transposition involves adjacent letter positions than when the transposition involves nonadjacent letter positions with two intervening letters. Furthermore, these models predict a reliable transposed-letter priming effect for nonadjacent transpositions (see Table 1).

\section{Method}

Participants

Forty-four students from the University of La Laguna received course credit for participating in the experiment. All of them either had normal or corrected-to-normal vision and were native speakers of Spanish.

\section{Materials}

The targets were 240 Spanish words that were 7-11 letters long (mean word frequency per one million words in the Spanish database, Davis \& Perea, 2005: 23, range: 1-147; mean Coltheart's N: 0.5 , range: $0-5$; mean length in letters: 8.9 , range: $7-11)$. The targets were presented in uppercase and were preceded by primes in lowercase that were (i) the same as the target except for a transposition of two adjacent internal letters (chocloate-CHOCOLATE); (ii) the same except for the substitution of two adjacent internal letters (chocduate-CHOCOLATE); (iii) the same as the target except for a transposition of two nonadjacent letter positions with two letters in between (e.g., choaolcte-CHOCOLATE); and (iv) the same except for the substitution of nonadjacent letter positions with two letters in between (choeolsteCHOCOLATE). The primes were always nonwords. The transpositions/substitutions occurred around the middle of the target words (mean length of target words $=8.9$ ). For the adjacent letter primes, the position of the two transposed/substituted letters was around the 4th and the 5th letter positions (mean: 4.5), and for the nonadjacent letter primes, the position of the two transposed/substituted letters was around the 3rd and the 6th letter positions (mean: 4.5). The letter transposition did not affect the morphemic boundaries of the word target (Christianson et al., 2005; Duñabeitia et al., 2007). (See Appendix for a complete list of target words and primes.) An additional set of 240 target pseudowords that were 7-11 letters long was included for the purposes of the lexical decision task. The manipulation of the pseudoword trials was the same as that for the word trials. Four lists of materials were constructed so that each target appeared once in each list, but each time in a different priming condition. Different groups of participants were assigned to each list.

\section{Procedure}

Participants were tested individually in a quiet room. Presentation of the stimuli and recording of response times were controlled by PC compatible computers. The experiment was run using DMDX (Forster \& Forster, 2003). Reaction times were measured from target onset until the participant's response. On each trial, a forward mask consisting of a row of hash marks (\#'s) was presented for $500 \mathrm{~ms}$ in the center
211

212

213

214

215

216

217

218

219

220

221

222

223

224

225

226

227

228

229

230

231

232

233

234

235

236

237

238

239

240

241

242

243 
of the screen. Next, the prime was presented in lowercase in 12-pt. Courier and stayed on the screen for $66 \mathrm{~ms}$ (4 cycles; each cycle corresponding to $16.6 \mathrm{~ms}$ on the CRT monitor). The prime was followed immediately by the presentation of the target stimulus in uppercase. Both prime and target were presented in the same screen location as the forward mask. The target remained on the screen until the participants responded or for 2,500 ms. Participants were instructed to press one of the two buttons on the keyboard to indicate whether the uppercase letter string was a legitimate word or not. Participants were also instructed to make this decision as quickly and as accurately as possible. Participants were not informed of the presence of lowercase items. Each participant received a different order of trials. Each participant received a total of 20 practice trials (with the same manipulation as in the experimental trials) prior to the 480 experimental trials. Participants reported no awareness of the lowercase stimuli when asked after the experiment. The whole session lasted approximately $16 \mathrm{~min}$.

\section{Results and Discussion}

Incorrect responses (3.3\% of the data for word targets) and reaction times less than $250 \mathrm{~ms}$ or greater than $1,500 \mathrm{~ms}$ ( $0.5 \%$ of the data for word targets) were excluded from the latency analysis. The mean latencies for correct responses and error rates are presented in Table 2, and participant and item ANOVAs based on the participant and item response latencies and error percentage were conducted based on a 2 (Type of Transposition/substitution: Adjacent, Nonadjacent) $\times 2$ (Type of nonword: Transposition, Substitution) $\times 4$ (List: list 1 , list 2, list 3, list 4) design. List was included as a dummy variable in the ANOVAs to extract the variance due to the error associated with the lists. All significant effects had $p$ values less than the .05 level.

\section{Word Data}

The ANOVAs on the latency data showed that words preceded by a transposed-letter prime were responded to $20 \mathrm{~ms}$ faster than the words preceded by a double-substitution prime, $F 1(1,40)=21.01 ; F 2(1,236)=26.58$, and that words preceded by an adjacent transposition/substitution prime were responded to $18 \mathrm{~ms}$ faster than the words preceded by a nonadjacent transposition/substitution prime, $F 1(1,40)=17.65 ; F 2(1,236)=29.28$. More importantly, the interaction between the two factors was significant, $F 1(1,40)=4.10 ; \quad F 2(1,236)=5.87 . \quad$ This interaction reflected that the transposed-letter priming effect was greater for adjacent transpositions $(27 \mathrm{~ms}), F 1(1,40)=25.44$; $F 2(1,236)=28.31$, than for nonadjacent transpositions $(14 \mathrm{~ms}), F 1(1,40)=5.34 ; F 2(1,236)=4.40$.

The ANOVA on the error data did not show any significant effects (all $p \mathrm{~s}>.10$ ).

\section{Nonword Data}

None of the ANOVAs on the nonword data was significant.

The results of this experiment were straightforward. There was a strong transposed-letter effect for adjacent transpositions $(27 \mathrm{~ms})$, which was smaller in magnitude (14 ms) - albeit significant - when the letter transpositions involved two intervening letters. Thus, it is possible to find a sizeable transposed-letter priming effect when the letter transpositions are three letters away. This finding poses a very strong problem for a position-specific coding scheme, but is entirely consistent with the predictions of the SOLAR, SERIOL, and open-bigram models (see Table 1).

\section{Experiment 2}

The goal of Experiment 2 was to replicate and extend the findings of Experiment 1 by adding a priming condition which involved the transposition of two nonadjacent letters with one intervening letter (e.g., cholocate-CHOCOLATE vs. the control chotonate-CHOCOLATE). This is a critical experiment to determine whether there is a gradual decrease as a function of the distance between the two transposed letters - note that all coding schemes predict an effect of the distance of the transpositions (see Table 1). Nonetheless, there are some differences across models in terms of the predicted effect size: The SERIOL model predicts that the difference across the two nonadjacent letter positions will be rather small, whereas the binary open-bigram model predicts a robust difference.
291

292

293

294

295

296

297

298

299

300

301

302

303

304

305

306

307

308

309

310

311

312

313

Table 2. Mean lexical decision times (in milliseconds) and percentage of errors (in parentheses) for word and nonword targets in Experiment 1

\begin{tabular}{lccr}
\hline & & Type of prime & \\
\cline { 2 - 4 } & Transposed-letter & Double-substitution & Priming \\
\hline Word trials & $702(3.0)$ & $729(3.1)$ & $27(0.1)$ \\
Adjacent & $726(3.3)$ & $740(3.7)$ & $14(0.4)$ \\
Nonadjacent (2 between) & & & \\
Nonword trials & $909(3.7)$ & $910(3.4)$ & $1(-0.3)$ \\
Adjacent & $907(3.0)$ & $902(3.4)$ & $-5(0.4)$ \\
Nonadjacent (2 between) & &
\end{tabular}


Method

\section{Participants}

Thirty-six students from the University of La Laguna received course credit for participating in the experiment. All of them either had normal or corrected-to-normal vision and were native speakers of Spanish.

\section{Materials}

The targets were the 240 words and 240 nonwords of Experiment 1 . The prime-target conditions were the same as in Experiment 1, except that we added two additional priming conditions. That is, the targets were presented in uppercase and were preceded by primes in lowercase that were (i) the same as the target except for a transposition of two adjacent internal letters, (chocloate-CHOCOLATE), (ii) the same except for the substitution of two adjacent internal letters (chocduate-CHOCOLATE), (iii) the same as the target except for the transposition of two nonadjacent internal letters, with one letter in between (cholocate-CHOCOLATE), (iv) the same except for the substitution of two nonadjacent internal letters, with one letter in between (chotonate-CHOCOLATE), (v) the same as the target except for a transposition of two nonadjacent letter positions with two letters in between (e.g., choaolcte-CHOCOLATE), and (vi) the same except for the substitution of nonadjacent letter positions with two letters in between (choeolste-CHOCOLATE). The primes were always nonwords. (see the Appendix for a complete list of target words and primes.) An additional set of 240 target pseudowords that were 7-11 letters long was included for the purposes of the lexical decision task - this was the same set as in Experiment 1. The manipulation of the pseudoword trials was the same as that for the word trials. Six lists of materials were constructed so that each target appeared once in each list, but each time in a different priming condition. Different groups of participants were assigned to each list.

\section{Procedure}

This was the same as in Experiment 1.

\section{Results and Discussion}

Incorrect responses (3.6\% of the data for word targets) and reaction times less than $250 \mathrm{~ms}$ or greater than $1,500 \mathrm{~ms}$ $(0.9 \%$ of the data for word targets) were excluded from the latency analysis. The mean latencies for correct responses and error rates are presented in Table 3. Participant and item ANOVAs based on the participant and item response latencies and error percentage were conducted based on a 3 (Type of transposition/substitution: Adjacent, Nonadjacent 1 letter, Nonadjacent 2 letters) $\times 2$ (Type of nonword: transposition, substitution) $\times 6$ (List: list 1 , list 2, list 3, list 4, list 5, list 6) design.

\section{Word Data}

The ANOVA on the latency data showed that words preceded by a transposed-letter prime were responded to $22 \mathrm{~ms}$ faster than the words preceded by a double-substitution prime, $F 1(1,30)=33.97 ; F 2(1,234)=40.37$. More importantly, there was a significant interaction between Type of nonword and Type of transposition/substitution, $F 1(2,60)=3.24 ; \quad F 2(2,468)=3.71$. This interaction reflected that the transposed-letter priming effect was greater for adjacent transpositions $(36 \mathrm{~ms}), F 1(1,30)=35.04$; $F 2(1,234)=32.29$, than for nonadjacent transpositions with one intervening letter $(17 \mathrm{~ms}), F 1(1,30)=6.99$; $F 2(1,234)=8.47$, and for nonadjacent transpositions with two intervening letters $(15 \mathrm{~ms}), \quad F 1(1,30)=4.59$; $F 2(1,234)=5.11$. (There were no differences in the size of the transposed-letter priming effect between the two nonadjacent conditions, both $F_{\mathrm{S}}<1$ ).

The ANOVA on the error data did not show any significant effects (all $p \mathrm{~s}>.14$ ).

\section{Nonword Data}

None of the ANOVAs on the nonword data was significant. Again, the results are straightforward. There was a significant transposed-letter priming effect for both adjacent and nonadjacent transposed-letter nonword primes relative
378

379

380

381

382

383

384

385

386

387

388

389

390

391

392

393

394

395

Table 3. Mean lexical decision times (in milliseconds) and percentage of errors (in parentheses) for word and nonword targets in Experiment 2

\begin{tabular}{lccc}
\hline & & Type of prime & \\
\cline { 2 - 4 } & Transposed-letter & Double-substitution & Priming \\
\hline Word trials & & & \\
Adjacent & $699(2.8)$ & $735(3.6)$ & $36(0.8)$ \\
Nonadjacent $(1$ between) & $715(3.3)$ & $732(3.4)$ & $17(0.1)$ \\
Nonadjacent (2 between) & $719(4.2)$ & $734(4.2)$ & $15(0.0)$ \\
Nonword trials & & & \\
Adjacent & $853(2.2)$ & $841(2.8)$ & $-12(0.6)$ \\
Nonadjacent (1 between) & $834(2.7)$ & $846(2.6)$ & $13(-0.1)$ \\
Nonadjacent (2 between) & $838(2.6)$ & $837(2.1)$ & $-1(-0.6)$ \\
\hline
\end{tabular}


401 to their appropriate orthographic control condition. As 402 expected, the magnitude of the transposed-letter priming 403 effect was greater when the transposition involved adjacent 404 letters than when it involved nonadjacent letters. Finally, 405 there were virtually no differences between transposing non406 adjacent letter positions with one or two intervening letters. 407 We examine these findings in the General Discussion.

\section{General Discussion}

What we should also note is that the obtained effects are not likely to be affected by syllabic structure. Leaving aside that the transposition of nonadjacent letter positions in the present experiment involves changes in two/three syllables (in particular for the condition with two intervening letters), Perea and Carreiras (2006c) found that the transposed-letter effect was of similar magnitude when two syllables were transposed and when two bigrams (that did not form a syllable) were transposed.

This is the first study that includes a parametric manipulation of the size of the letter transpositions (number of intervening letters: 0,1 , and 2 letters). The main findings of the present experiments are clear-cut and have clear implication for the choice of an input coding scheme in models of visual-word recognition. First, masked transposed-letter priming effects occur not only for adjacent letter positions (chocloate-CHOCOLATE) but also - to a lesser degree - for nonadjacent letter positions with one and two intervening letters (cholocate-CHOCOLATE and choaolcte-CHOCOLATE). Second, the transposed-letter priming effect was almost of the same size for nonadjacent transpositions that involved one intervening letter and for nonadjacent transpositions that involved two nonadjacent letters.

The presence of a sizeable transposed-letter priming effect for nonadjacent pairs with two intervening letters (choaolcte-CHOCOLATE vs. the control choeolste-CHOCOLATE) strongly suggests that the cognitive system uses a rather flexible code to encode internal letter positions (see also Guerrera \& Forster, in press; Humphreys, Evett, \& Quinlan, 1990; Perea \& Carreiras, 2006c). What are the implications for the coding schemes that are able to capture transposed-letter priming effects (i.e., SOLAR, SERIOL, and open-bigram models)? These input coding schemes correctly make the prediction that the transposed-letter effect should be greater for adjacent transpositions than for nonadjacent transpositions - relative to the appropriate control condition. ${ }^{3}$ The problem arises when we compare the transposed-letter priming effects that involved nonadjacent transpositions. The SOLAR model - at least when using the default parameters of the model - predicts a robust transposed-letter priming effect for the adjacent transpositions, a smaller transposed-letter effect for the nonadjacent transpositions (with one intervening letter), and a close-tonull transposed-letter effect for nonadjacent transpositions (with two intervening letters). The binary open-bigram model has a similar problem. It predicts a much smaller transposed-letter priming effect for nonadjacent than for adjacent letter transpositions (especially when the transpositions involve two intervening letters). In contrast, the SERIOL model predicts a strong transposed-letter priming effect for adjacent letter positions, and a smaller priming effect for nonadjacent letter positions (with one or two intervening letters), which is entirely consistent with the pattern of data obtained in Experiments 1 and 2. Nonetheless, we must take the predicted similarity values of the models with caution. There is a lack of sensitivity to lexical processing (or topdown processing in general) in the similarity match values (see also Acha \& Perea, in press; Guerrera \& Forster, in press; Welvaert, Farioli, \& Grainger, 2008). These values just reflect the similarity between two letter strings, without taking into account that there are other factors influencing the degree of perceptual similarity between two words in memory. A fully implemented version of the SOLAR, SERIOL, or open-bigram models would be necessary to obtain predicted values concerning the transposed-letter priming effect. What is clear, however, is that these models should be able to capture a graded transposed-letter effect when comparing adjacent versus nonadjacent transpositions and, at the same time, they should not predict a difference (or a very small effect) when comparing transposed-letter effects for nonadjacent (internal) letter positions.

In sum, the present experiments have shown that transposed-letter priming effects are a robust phenomenon that survives even when the letter transpositions involve two intervening (internal) letters. Undoubtedly, the brain allows an important degree of flexibility in coding internal letter positions. The SOLAR, the open-bigram, and (especially) the SERIOL model do a fine job of predicting some of the observed transposed-letter priming effects, although a full implementation of these models is required to assess their fits to the data.

\section{Acknowledgments}

This research was partially supported by grants from the Spanish Ministry of Education and Science (SEJ200407680-C02-02/PSIC, SEJ2005-05205/EDU; PR2007-0201; SEJ2006-09238). Jon Andoni Duñabeitia was the recipient of a post-graduate grant from the Basque Government. We thank Ken Forster and two anonymous reviewers for helpful comments on an earlier version of the paper.

A "distance" effect would also be predicted by the overlap model (Gómez, Ratcliff, \& Perea, submitted for publication). In the overlap model, for any string of letters, the positions of the letters are assumed to be distributed over position. For instance, if the string of letters is the word TRIAL, the letter I will be associated with position 3, but also, to a lesser degree, to positions 2 and 4 , and even to positions 1 and 


\section{References}

Acha, J., \& Perea, M. (in press). The effects of length and transposed-letter similarity in lexical decision: Evidence with beginning, intermediate, and adult readers. British Journal of Psychology.

Christianson, K., Johnson, R. L., \& Rayner, K. (2005). Letter transpositions within and across morphemes. Journal of Experimental Psychology: Learning, Memory, \& Cognition, 31, 1327-1339.

Coltheart, M., Rastle, K., Perry, C., Ziegler, J., \& Langdon, R. (2001). DRC: A Dual-Route Cascaded model of visual word recognition and reading aloud. Psychological Review, 108, 204-256.

Davis, C. J. (1999). The Self-Organising Lexical Acquisition and Recognition (SOLAR) model of visual word recognition. University of New South Wales: Unpublished doctoral dissertation.

Davis, C. J., \& Perea, M. (2005). BuscaPalabras: A program for deriving orthographic and phonological neighborhood statistics and other psycholinguistic indices in Spanish. Behavior Research Methods, 37, 665-671.

Duñabeitia, J. A., Perea, M., \& Carreiras, M. (2007). Do transposed-letter similarity effects occur at a morpheme level? Evidence for ortho-morphological decomposition. Cognition, 105, 691-703.

Forster, K. I., Davis, C., Schoknecht, C., \& Carter, R. (1987). Masked priming with graphemically related forms: Repetition or partial activation? Quarterly Journal of Experimental Psychology, 39, 211-251.

Forster, K. I., \& Forster, J. C. (2003). DMDX: A Windows display program with millisecond accuracy. Behavior Research Methods, Instruments, \& Computers, 35, 116-124.

Gómez, P., Ratcliff, R., \& Perea, M. (submitted for publication). The overlap model: A model of letter position coding.

Grainger, J. (in press). Cracking the orthographic code: An introduction to the special issue on orthographic processes in reading. Language and Cognitive Processes.

Grainger, J., Granier, J. P., Farioli, F., Van Assche, E., \& van Heuven, W. (2006). Letter position information and printed word perception: The relative-position priming constraint. Journal of Experimental Psychology: Human Perception and Performance, 32, 865-884.

Grainger, J., \& Jacobs, A. M. (1996). Orthographic processing in visual word recognition: A multiple read-out model. Psychological Review, 103, 518-565.

Grainger, J., \& van Heuven, W. J. B. (2003). Modeling letter position coding in printed word perception. In P. Bonin (Ed.), The mental lexicon (pp. 1-23). New York: Nova Science.

Grainger, J., \& Whitney, C. (2004). Does the huamn mind raed wrods as a wlohe? Trends in Cognitive Sciences, 8, 5859.

Guerrera, C., \& Forster, K. I. (in press). Masked form priming with extreme transposition. Language and Cognitive Processes.

Humphreys, G. W., Evett, L. J., \& Quinlan, P. T. (1990). Early orthographic processing in visual word recognition. Cognitive Psychology, 22, 517-560.

Johnson, R. L. (2007). The flexibility of letter coding: Nonadjacent letter transposition effects in the parafovea. In R. van Gompel, M. Fisher, W. Murray, \& R. L. Hill (Eds.). Eye movements: A window on mind and brain (pp. 425-440). Oxford: Elsevier.

Johnson, R. L., Perea, M., \& Rayner, K. (2007). Transposedletter effects in reading: Evidence from eye movements and parafoveal preview. Journal of Experimental Psychology: Human Perception and Performance, 33, 209-229.
Lupker, S. J., Perea, M., \& Davis, C. J. (in press). Transposed letter priming effects: Consonants, vowels and letter frequency. Language and Cognitive Processes.

Perea, M., \& Carreiras, M. (2006a). Do transposed-letter similarity effects occur at a prelexical phonological level? Quarterly Journal of Experimental Psychology, 59, 1600 1613.

Perea, M., \& Carreiras, M. (2006b). Do transposed-letter effects occur across lexeme boundaries? Psychonomic Bulletin \& Review, 13, 418-422.

Perea, M., \& Carreiras, M. (2006c). Do transposed-letter similarity effects occur at a syllable level? Experimental Psychology, 53, 308-315.

Perea, M., \& Lupker, S. J. (2003a). Does jugde activate COURT? Transposed-letter similarity effects in masked associative priming. Memory \& Cognition, 31, 829-841.

Perea, M., \& Lupker, S. J. (2003b). Transposed-letter confusability effects in masked form priming. In S. Kinoshita \& S. J. Lupker (Eds.). Masked priming: State of the art (pp. 97 120). Hove, UK: Psychology Press.

Perea, M., \& Lupker, S. J. (2004). Can CANISO activate CASINO? Transposed-letter similarity effects with nonadjacent letter positions. Journal of Memory and Language, 51, 231-246.

Rayner, K., White, S., Johnson, R. L., \& Liversedge, S. (2006). Raeding wrods with jubmled lettres: There's a cost. Psychological Science, 17, 192-193.

Rumelhart, D. E., \& McClelland, J. L. (1982). An interactive activation model of context effects in letter perception: Part 2 . The contextual enhancement effect and some tests and extensions of the model. Psychological Review, 89, 60-94.

Schoonbaert, S., \& Grainger, J. (2004). Letter position coding in printed word perception: Effects of repeated and transposed letters. Language and Cognitive Processes, 19, 333-367.

Welvaert, M., Farioli, F., \& Grainger, J. (2008). Graded effects of number of inserted letters in superset priming. Experimental Psychology, 55, 54-63.

Whitney, C. (2001). How the brain encodes the order of letters in a printed word: The SERIOL model and selective literature review. Psychonomic Bulletin \& Review, 8, 221-243.

Whitney, C. (in press). A comparison of the SERIOL and SOLAR theories of letter-position encoding. Brain and Language.

Whitney, C., \& Cornelissen, R. (in press). SERIOL reading. Language and Cognitive Processes.

\section{Appendix}

\section{Experimental Nonword-Word Pairs}

The items are arranged in quintuplets in the following order: Transposed-letter Prime (adjacent), double-substitution prime (adjacent), Transposed-letter Prime (one letter inbetween; Experiment 2), double-substitution prime (one letter inbetween; Experiment 2), Transposed-letter Prime (two letters inbetween), double-substitution prime (two letters inbetween), and target word.

favroito, favneito, farovito, famonito, faiorvto, fauorzto, FAVORITO; nictoina, nicraina, nitocina, niborina, niiotcna, niuotsna, NICOTINA; persnoaje, persmeaje, pernosaje, permoraje, peraonsje, pereonrje, PERSONAJE; benfeicio, bentiicio, befenicio, betesicio, beiefncio, beoefrcio, BENEFICIO; vehciulo, vehmeulo, vecihulo, vemitulo, veuichlo, veoicflo, VEHICULO; vestbiulo, vestdeulo, vesbitulo, 
vesdifulo, vesuibtlo, vesoibflo, VESTIBULO; vitlaidad, vitbeidad, vilatidad, vibadidad, viialtdad, vioalfdad, VITALIDAD; fidleidad, fidtaidad, filedidad, fitebidad, fiielddad, fioelbdad, FIDELIDAD; rigruosa, rigsiosa, rirugosa, risuposa, riourgsa, riuurpsa, RIGUROSA; ertoica, erlaica, etorica, elosica, eiotrca, euotsca, EROTICA; herdeado, herbaado, hederado, hebesado, heaedrdo, heeedsdo, HEREDADO; abnaico, abceico, anabico, acadico, aianbco, aoandco, ABANICO; medtiacion, medteacion, metidacion, melifacion, meaitdcion, meeitbcion, MEDITACION; parlaelo, partoelo, palarelo, pataselo, paealrlo, paaalslo, PARALELO; cermeonia, cernaonia, cemeronia, ceseconia, ceoemrnia, ceuemsnia, CEREMONIA; dormtiorio, dormleorio, dortimorio, dorlirorio, doroitmrio, doruitsrio, DORMITORIO; disloucion, distiucion, dilosucion, ditorucion, diuolscion, dioolrcion, DISOLUCION; delciado, delnuado, decilado, denifado, deaicldo, deeicfdo, DELICADO; genreales, gensaales, gerenales, gesezales, geaernles, geeersles, GENERALES; serneidad, sermaidad, seneridad, sevesidad, seienrdad, seoensdad, SERENIDAD; cazdaores, cazbeores, cadazores, calanores, caoadzres, cauadvres, CAZADORES; litreatura, litnaatura, liretatura, linebatura, liaerttura, lieerltura, LITERATURA; capcaidad, capneidad, cacapidad, canagidad, caiacpdad, cauacgdad, CAPACIDAD; captiulo, capboulo, catipulo, cabigulo, cauitplo, caoitglo, CAPITULO; camraero, camzoero, caramero, cazanero, caearmro, caaarsro, CAMARERO; comnuicar, comsiicar, conumicar, cosuvicar, coiunmcar, coounrcar, COMUNICAR; tecnloogico, tecndeogico, tecnogolico, tecnopotico, tecoolngico, tecuolsgico, TECNOLOGICO; ridciulo, ridneulo, ricidulo, rinitulo, riuicdlo, rioicblo, RIDICULO; genreoso, gensaoso, gerenoso, gesevoso, geoernso, geuercso, GENEROSO; mensjaero, mensgeero, menjasero, mengarero, meneajsro, menaajcro, MENSAJERO; diplomtaico, diplomleico, diplotamico, diplobarico, dimlopatico, dirlogatico, DIPLOMATICO; dispnoible, dispmaible, disnopible, dismogible, disionpble, disoongble, DISPONIBLE; privliegio, privtuegio, prilivegio, pritisegio, prieilvgio, priailngio, PRIVILEGIO; perfieria, perteeria, pefireria, petimeria, peeifrria, peoifsria, PERIFERIA; vetreano, vetsaano, veretano, vesebano, veaertno, veeerlno, VETERANO; formdiable, formboable, fordimable, fortirable, foraidmble, foreidsble, FORMIDABLE; hiptoesis, hipbuesis, hitopesis, hibogesis, hieotpsis, hiaotqsis, HIPOTESIS; vocbaulario, vocdeulario, vobaculario, votanulario, vouabclario, vooabrlario, VOCABULARIO; avneida, avmaida, anevida, acerida, aienvda, aoenzda, AVENIDA; marvailla, marneilla, mavarilla, manamilla, maiavrlla, maeavslla, MARAVILLA; fortlaeza, fortfeeza, forlateza, forbadeza, forealtza, foraallza, FORTALEZA; opsoicion, opnaicion, osopicion, onogicion, oiospcion, ooosgcion, OPOSICION; almuinio, alneinio, amulinio, asubinio, aiumlnio, aoumtnio, ALUMINIO; popluares, poptiares, polupares, potujares, poaulpres, pooulgres, POPULARES; labroatorio, labseatorio, larobatorio, lasotatorio, laaorbtorio, laoordtorio, LABORATORIO; estbailidad, estdeilidad, esbatilidad, esdalilidad, esiabtlidad, esuabllidad, ESTABILIDAD; leglaidad, legteidad, lelagidad, lebapidad, leialgdad, leoalpdad, LEGALIDAD; jubliacion, jubduacion, julibacion, jutidacion, juailbcion, jueildcion, JUBILACION; comnuidad, comroidad, conumidad, covusidad, coiunmdad, coeunsdad,
COMUNIDAD; cadvaeres, cadnoeres, cavaderes, canateres, caeavdres, caaavtres, CADAVERES; humnaidad, humseidad, hunamidad, husaridad, huianmdad, huoansdad, HUMANIDAD; femneino, femsaino, fenemino, fesecino, feienmno, feoensno, FEMENINO; orgnaico, orgsoico, ornagico, orsapico, oriangco, oroanpco, ORGANICO; añdaido, añfeido, adañido, afasido, aiadñdo, aoadzdo, AÑADIDO; artciulo, artnoulo, arcitulo, arnibulo, aruictlo, ariicllo, ARTICULO; misreables, mismaables, miresables, mimenables, miaersbles, mieerrbles, MISERABLES; semniario, semsuario, senimario, sesirario, seainmrio, seeinsrio, SEMINARIO; velcoidad, velneidad, vecolidad, venotidad, veiocldad, veooctdad, VELOCIDAD; despdeida, despbaida, desdepida, desbeyida, desiedpda, desoedgda, DESPEDIDA; pelciula, pelnoula, pecilula, penibula, peuiclla, peiictla, PELICULA; anmiales, anruales, aminales, arivales, aaimnles, aeimsles, ANIMALES; testmionio, testvuonio, tesmitonio, tesvilonio, tesoimtnio, tesuimlnio, TESTIMONIO; polmeica, polnaica, pomelica, posetica, poiemlca, pooemtca, POLEMICA; lumnioso, lumsuoso, lunimoso, lusiroso, luoinmso, luiinsso, LUMINOSO; estmoago, estreago, esmotago, esnolago, esaomtgo, eseomlgo, ESTOMAGO; podreoso, podmaoso, poredoso, pometoso, pooerdso, pouerbso, PODEROSO; molceulas, molsaulas, mocelulas, monedulas, mouecllas, mooectlas, MOLECULAS; reptuacion, repliacion, retupacion, rebugacion, reautpcion, reeutgcion, REPUTACION; reltaividad, relfeividad, retalividad, rebadividad, reiatlvidad, reoattvidad, RELATIVIDAD; pardaoja, parbeoja, padaroja, patasoja, paoadrja, paaadsja, PARADOJA; parmaetros, parnoetros, pamaretros, pasavetros, paeamrtros, paaamstros, PARAMETROS; redcuido, redsoido, recudido, renutido, reiucddo, reuucbdo, REDUCIDO; metlaico, metbeico, melatico, mebadico, meialtco, meuallco, METALICO; genteica, genlaica, getenica, gelemica, geietnca, geuetsca, GENETICA; pasjaeros, paspoeros, pajaseros, papameros, paeajsros, paaajrros, PASAJEROS; kilmoetros, kilsietros, kimoletros, kisotetros, kieomltros, kiaomttros, KILOMETROS; repteicion, replaicion, retepicion, relegicion, reietpcion, reoetdcion, REPETICION; retroica, retmuica, rerotica, remofica, reiortca, reoorlca, RETORICA; amnaecer, amsiecer, anamecer, asavecer, aeanmcer, aaanrcer, AMANECER; amneaza, amsiaza, anemaza, asevaza, aaenmza, aeenrza, AMENAZA; semfaoro, semteoro, sefamoro, setacoro, seoafmro, seiafsro, SEMAFORO; obligtaorio, obligleorio, oblitagorio, oblifaporio, oglibatorio, oplidatorio, OBLIGATORIO; almcaenes, almsoenes, alcamenes, alsarenes, aleacmnes, alaacsnes, ALMACENES; tabruete, tabniete, tarubete, tanufete, taeurbte, taaurdte, TABURETE; zaptaillas, zapleillas, zatapillas, zabagillas, zaiatpllas, zaoatdllas, ZAPATILLAS; aprendziaje, aprendsuaje, aprenzidaje, aprensitaje, anrepdizaje, asrejdizaje, APRENDIZAJE; obstcaulo, obstneulo, obscatulo, obsnabulo, obsuactlo, obsoacllo, OBSTACULO; prefreido, prefsaido, prerefido, presetido, preierfdo, preoertdo, PREFERIDO; comteido, comlaido, cotemido, colevido, coietmdo, cooetsdo, COMETIDO; agtoado, agliado, atogado, alopado, aaotgdo, aeotpdo, AGOTADO; natrualeza, natsialeza, narutaleza, nasulaleza, naaurtleza, naeurlleza, NATURALEZA; fenmoeno, fenrueno, femoneno, feroveno, feeomnno, feaomrno, FENOMENO; camsieta, camnueta, casimeta, caniveta, caeismta, caaissta, CAMISETA; biolgoica, bioljeica, 
biogolica, biopodica, bioioglca, biooogtca, BIOLOGICA; comdoidad, comtuidad, codomidad, cotosidad, coiodmdad, couodsdad, COMODIDAD; marniero, marsaero, manirero, masivero, maeinrro, maaincro, MARINERO; desyauno, desgeuno, deyasuno, degavuno, deuaysno, deoaycno, DESAYUNO; catlaogo, catfeogo, calatogo, cabadogo, caoaltgo, cauallgo, CATALOGO; gasloina, gasteina, galosina, gatorina, gaiolsna, gaoolcna, GASOLINA; gramtaica, gramfeica, gratamica, grabasica, graiatmca, graoatnca, GRAMATICA; chocloate, chocduate, cholocate, chotonate, choaolcte, choeolste, CHOCOLATE; libreacion, libnaacion, lirebacion, linetacion, liaerbcion, lieerdcion, LIBERACION; predmoinio, predseinio, premodinio, presotinio, preiomdnio, preuombnio, PREDOMINIO; emsiora, emcuora, esimora, ecirora, eoismra, euissra, EMISORA; respteable, resploable, restepable, resbegable, resaetpble, reseetgble, RESPETABLE; finlaidad, finteidad, filanidad, fibasidad, fiialndad, fioalsdad, FINALIDAD; fumdaores, fumbeores, fudamores, fulasores, fuoadmres, fuuadrres, FUMADORES; sindciato, sindnuato, sincidato, sinsibato, sinaicdto, sineicbto, SINDICATO; depsoito, depnuito, desopito, denogito, deiospto, deoosdto, DEPOSITO; tonleadas, tontoadas, tolenadas, tobemadas, toaelndas, toeelrdas, TONELADAS; agjuero, agpiero, ajugero, apujero, aeujgro, aaujpro, AGUJERO; edtiorial, edfuorial, etidorial, eliforial, eoitdrial, euitbrial, EDITORIAL; diptuado, dipliado, ditupado, didujado, diautpdo, dieutddo, DIPUTADO; camraote, camseote, caramote, casacote, caoarmte, cauarste, CAMAROTE; dimniuto, dimcauto, dinimuto, disivuto, diuinmto, dioinsto, DIMINUTO; satleite, satfaite, saletite, sabedite, saieltte, saoellte, SATELITE; mejciano, mejnuano, mecijano, mesipano, meaicjno, meeicpno, MEJICANO; irnoico, irseico, inorico, isovico, iionrco, ioonsco, IRONICO; jardniero, jardcoero, jarnidero, jarsitero, jandirero, jardisero, JARDINERO; panroama, pansuama, paronama, pasovama, paaornma, paeorrma, PANORAMA; amreicano, amsaicano, aremicano, asesicano, aiermcano, aoerrcano, AMERICANO; salduable, salbiable, sadulable, satubable, saaudlble, saeudtble, SALUDABLE; mamfieros, mamtaeros, mafimeros, matiseros, maeifmros, maaifsros, MAMIFEROS; disctoeca, discfaeca, distoceca, disboneca, diseotcca, disaotnca, DISCOTECA; envergdaura, envergbeura, enverdagura, envertapura, engervadura, enpernadura, ENVERGADURA; disñeado, disvoado, diñesado, divemado, diaeñsdo, dieeñndo, DISEÑADO; retriada, retsoada, reritada, resilada, reairtda, reeirlda, RETIRADA; exgaerado, exjoerado, exaregado, exasepado, eeagxrado, eaagzrado, EXAGERADO; ibreica, ibnaica, irebica, isetica, iierbca, ioerdca, IBERICA; modreacion, modmoacion, moredacion, momebacion, moaerdcion, moeerbcion, MODERACION; mecnaico, mecreico, menacico, meravico, meiancco, meoansco, MECANICO; partdiarios, partbuarios, parditarios, parlibarios, paraidtrios, pareidlrios, PARTIDARIOS; porcleana, porctoana, porlecana, porfesana, poraelcna, poreelsna, PORCELANA; catloica, catfuica, calotica, cadobica, caioltca, caoolfca, CATOLICA; pesdaillas, pesbeillas, pedasillas, petanillas, peiadsllas, peoadnllas, PESADILLAS; mutliado, mutbuado, mulitado, mudibado, muailtdo, mueilfdo, MUTILADO; alterntaiva, alternfeiva, altertaniva, alterbasiva, alnertativa, alserfativa, ALTERNATIVA; propsoicion, propnuicion, prosopicion, proroyicion, proiospcion, prouosgcion,
PROPOSICION; tempreatura, tempsoatura, tempetarura, tempebamura, temaerptura, temeergtura, TEMPERATURA; andlauces, andteuces, anladuces, antabuces, anualdces, anoalbces, ANDALUCES; britnaico, britseico, brinatico, brisabico, briiantco, brioanlco, BRITANICO; undiades, unfuades, udinades, utisades, uaidndes, ueidcdes, UNIDADES; valroacion, valsuacion, varolacion, vamotacion, vaaorlcion, vaeortcion, VALORACION; labroables, labneables, larobables, lanodables, laaorbbles, laeordbles, LABORABLES; anlaisis, anteisis, alanisis, atarisis, aialnsis, aoalcsis, ANALISIS; matmeaticas, matsiaticas, matetamicas, matelasicas, maaemtticas, maeemlticas, MATEMATICAS; primvaera, primniera, privamera, prisarera, prieavmra, priaavrra, PRIMAVERA; plurlaidad, plurteidad, plularidad, plutasidad, pluialrdad, pluualsdad, PLURALIDAD; dramtaico, dramleico, dratamico, drabasico, draiatmco, drauatcco, DRAMATICO; enmeigo, ensaigo, emenigo, eserigo, eiemngo, eoemcgo, ENEMIGO; evloutiva, evfiutiva, elovutiva, etonutiva, euolvtiva, eiolztiva, EVOLUTIVA; santiario, sanluario, satinario, sabisario, saaitnrio, saeitsrio, SANITARIO; japnoesa, japsiesa, janopesa, jasojesa, jaeonpsa, jaaongsa, JAPONESA; captialista, caplualista, catipalista, calijalista, caaitplista, caeitglista, CAPITALISTA; cocniera, cocsaera, conicera, cosivera, coeincra, coainsra, COCINERA; enmaorado, enceorado, emanorado, ecasorado, eoamnrado, euamcrado, ENAMORADO; ejceutivo, ejsautivo, ejetucivo, ejebunivo, euecjtivo, eoecptivo, EJECUTIVO; volmuenes, volcienes, vomulenes, vosutenes, voeumlnes, voaumtnes, VOLUMENES; autroidad, autsuidad, aurotidad, auvolidad, auiortdad, auuorldad, AUTORIDAD; dinmaica, dinseica, dimanica, disarica, diiamnca, diuamrca, DINAMICA; abgoado, abpiado, agobado, apotado, aaogbdo, aeogddo, ABOGADO; simluacion, simtiacion, silumacion, sibusacion, siaulmcion, sieulscion, SIMULACION; elbaorar, elteorar, ebalorar, etadorar, eoablrar, euabtrar, ELABORAR; silciona, silsuona, sicilona, simitona, sioiclna, siuictna, SILICONA; negtaivo, negfoivo, netagivo, nelapivo, neiatgvo, neoatpvo, NEGATIVO; denmoinado, dencainado, demoninado, decorinado, deiomnnado, deoomrnado, DENOMINADO; opreacion, opsoacion, orepacion, osejacion, oaerpcion, oeergcion, OPERACION; tripluacion, triptiacion, trilupacion, tritugacion, triaulpcion, trieulgcion, TRIPULACION; apraicion, apseicion, arapicion, asagicion, aiarpcion, aoargcion, APARICION; frivloidad, frivfuidad, frilovidad, fridonidad, friiolvdad, frioolzdad, FRIVOLIDAD; soldiaridad, solbearidad, sodilaridad, sobifaridad, soaidlridad, soeidtridad, SOLIDARIDAD; marpiosas, margeosas, mapirosas, magisosas, maoiprsas, mauipssas, MARIPOSAS; vegteales, vegboales, vetegales, vebepales, veaetgles, veeetples, VEGETALES; penstaivo, pensleivo, pentasivo, pendamivo, peniatsvo, penoatrvo, PENSATIVO; epsiodio, epcuodio, esipodio, enigodio, eoispdio, euisqdio, EPISODIO; antaomia, anleomia, atanomia, abasomia, aoatnmia, auatsmia, ANATOMIA; remloino, remtaino, relomino, retorino, reiolmno, reuolnno, REMOLINO; ilmuinado, ilsoinado, ilunimado, ilusirado, iiumlnado, ioumtnado, ILUMINADO; radciales, radneales, racidales, ranitales, raaicdles, raeicbles, RADICALES; atmoica, atsuica, amotica, asolica, aiomtca, aoomlca, ATOMICA; ordneador, ordviador, ornedador, orvetador, oraenddor, oreenbdor, ORDENADOR; totlaidad, totbeidad, tolatidad, tobadidad, toialtdad, toualldad, 
TOTALIDAD; dismiular, disroular, dimisular, dinirular, diuimslar, dioimrlar, DISIMULAR; catgeoria, catpaoria, cagetoria, capeboria, caoegtria, caueglria, CATEGORIA; corzaones, cormeones, cozarones, comanones, cooazrnes, couazsnes, CORAZONES; acsuado, acniado, asucado, amunado, aauscdo, aeussdo, ACUSADO; miltiares, milfoares, mitilares, mibifares, miaitlres, mieittres, MILITARES; delgeado, delpoado, degelado, depetado, deaegldo, deeegtdo, DELEGADO; consdierar, consbaerar, condiserar, continerar, coneidsrar, conaidrrar, CONSIDERAR; genreacion, gensoacion, gerenacion, gesevacion, geaerncion, geeerccion, GENERACION; domniacion, domcuacion, donimacion, doviracion, doainmcion, doeinscion, DOMINACION; filsoofico, filniofico, filofosico, filotonico, fiooslfico, fiuostfico, FILOSOFICO; asseinato, ascainato, asenisato, asecirato, aiessnato, aoesrnato, ASESINATO; estmiulante, estsoulante, esmitulante, esnibulante, esuimtlante, esiimllante, ESTIMULANTE; abslouto, absfeuto, ablosuto, abconuto, abuolsto, abiolrto, ABSOLUTO; vitmainas, vitseinas, vimatinas, vicadinas, viiamtnas, vioamlnas, VITAMINAS; apteito, aplaito, atepito, alejito, aietpto, aoetgto, APETITO; colroado, colsuado, corolado, cosotado, coaorldo, coeortdo, COLORADO; titluado, titbiado, tilutado, tibufado, tiaultdo, tieulldo, TITULADO; aljeado, alpaado, ajelado, apebado, aaejldo, aeejtdo, ALEJADO; profseores, profmaores, prosefores, promelores, prooesfres, prouestres, PROFESORES; dentdaura, dentfeura, dendatura, denbalura, denuadtra, denoadlra, DENTADURA; navdiades, navbuades, nadivades, natisades, naaidvdes, naeidcdes, NAVIDADES; desliusion, destousion, delisusion, detimusion, deuilssion, deiilcsion, DESILUSION; minreales, minsoales, mirenales, misevales, miaernles, mieerrles, MINERALES; edcuacion, edneacion, ecudacion, enutacion, eaucdcion, eeucbcion, EDUCACION; segruidad, segmoidad, serugidad, senupidad, seiurgdad, seourjdad, SEGURIDAD; intleigente, intbaigente, inletigente, indebigente, inieltgente, inoellgente, INTELIGENTE; telveision, telraision, tevelision, teredision, teievlsion, teoevtsion, TELEVISION; desloacion, destuacion, delosacion, deboracion, deaolscion, deeolrcion, DESOLACION; almeanes, alsianes, amelanes, asebanes, aaemlnes, aeemtnes, ALEMANES; detneido, detcaido, denetido, develido, deientdo, deoenldo, DETENIDO; navgeacion, navpoacion, nagevacion, napesacion, naaegvcion, naeegncion, NAVEGACION; señroita, señsuita, seroñita, semovita, seiorñta, seoorzta, SEÑORITA; elveada, elnoada, evelada, enetada, eaevlda, eeevtda, ELEVADA; metfaora, metleora, mefatora, melabora, meoaftra, meuaflra, METAFORA; concoida, consaida, coconida, covosida, coiocnda, couocrda, CONOCIDA; revloucion, revtiucion, relovucion, reborucion, reuolvcion, reiolncion, REVOLUCION; limtiada, limluada, litimada, libisada, liaitmda, lieitsda, LIMITADA; milmietros, milsoetros, mimiletros, misitetros, mieimltros, miaimttros, MILIMETROS; invtiacion, invleacion, intivacion, indisacion, inaitvcion, ineitncion, INVITACION; homneaje, homviaje, honemaje, hosevaje, hoaenmje, hoeenrje, HOMENAJE; raznoable, razcuable, ranozable, rasovable, raaonzble, raeonñble, RAZONABLE; comsiario, comneario, cosimario, corivario, coaismrio, coeissrio, COMISARIO; escpoeta, escgieta, espoceta, esgometa, eseopcta, esaoprta, ESCOPETA; soltiario, solleario, sotilario, sobidario, soaitlrio, soeittrio, SOLITARIO; amraillo, amseillo, aramillo, asavillo, aiarmllo, auarsllo, AMARILLO; telfeono, teltaono, tefelono, tedetono, teoeflno, teueftno, TELEFONO; resloucion, restiucion, relosucion, retovucion, reuolscion, reoolrcion, RESOLUCION; supreacion, supsoacion, surepacion, susegacion, suaerpcion, sueerjcion, SUPERACION; informtaica, informleica, infortamica, infordasica, inmorfatica, insortatica, INFORMATICA; mortlaidad, mortbeidad, morlatidad, morbafidad, morialtdad, moroalldad, MORTALIDAD; imgaenes, impienes, igamenes, iparenes, ieagmnes, iaagsnes, IMAGENES; elgeido, elpaido, egelido, epebido, eiegldo, eoegtdo, ELEGIDO; decroacion, decsuacion, derocacion, demovacion, deaorccion, deeorscion, DECORACION; termniada, termceada, ternimada, tersicada, terainmda, tereinsda, TERMINADA; revleacion, revtoacion, relevacion, retemacion, reaelvcion, reeelncion, REVELACION; metfaisica, metleisica, mefatisica, medabisica, meiaftsica, meoaflsica, METAFISICA; sabdiuria, sabtouria, sadiburia, satiluria, sauidbria, saiiddria, SABIDURIA; sobreania, sobmiania, sorebania, somelania, soaerbnia, soeerdnia, SOBERANIA.

Received February 8, 2007

Revision received October 10, 2007

Accepted October 17, 2007

Manuel Perea

Departamento de Metodología

Facultad de Psicología

Av. Blasco Ibáñez

21, 46010 Valencia, Spain

E-mailmperea@valencia.edu 